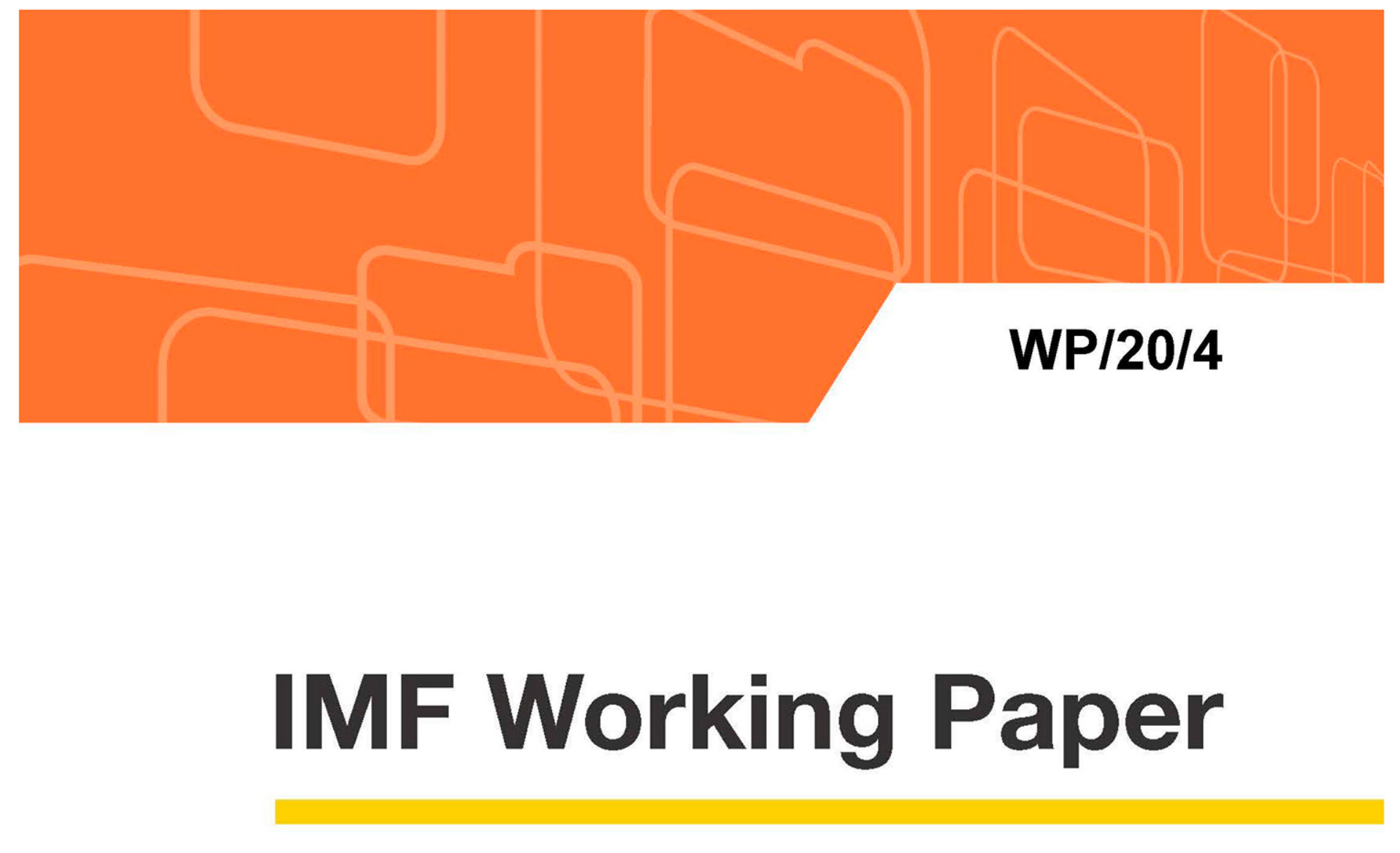

\title{
Monetary Policy Is Not Always Systematic and Data-Driven: Evidence from the Yield Curve
}

by Aleš Bulíř and Jan Vlček

IMF Working Papers describe research in progress by the author(s) and are published to elicit comments and to encourage debate. The views expressed in IMF Working Papers are those of the author(s) and do not necessarily represent the views of the IMF, its Executive Board, or IMF management.

$$
\text { I N T E R N A T I O N A L M O N E T A R Y F U N D }
$$




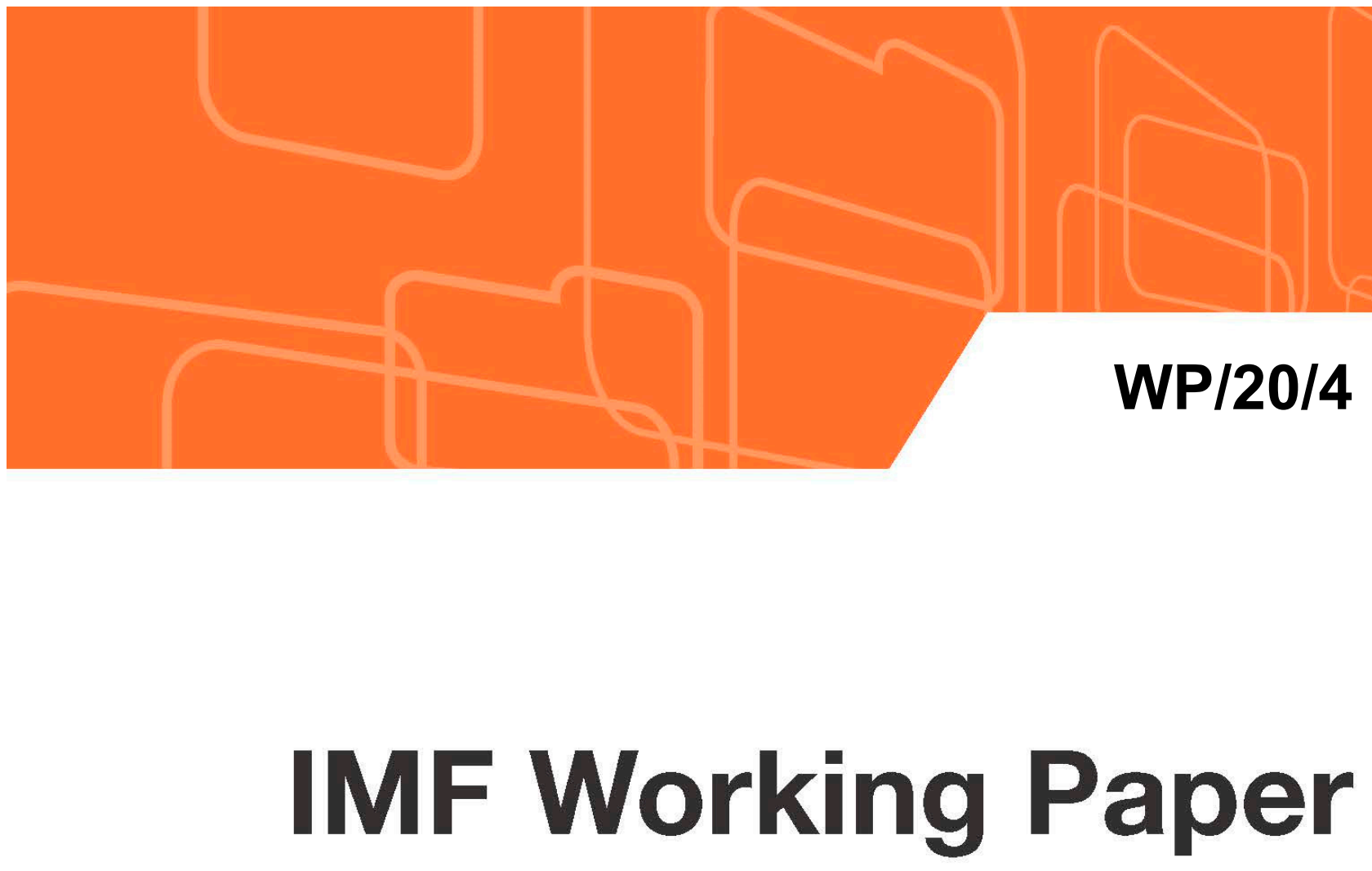

\section{Monetary Policy Is Not Always Systematic and Data-Driven: Evidence from the Yield Curve}

by Aleš Buliř and Jan Vlček

IMF Working Papers describe research in progress by the author(s) and are published to elicit comments and to encourage debate. The views expressed in IMF Working Papers are those of the author(s) and do not necessarily represent the views of the IMF, its Executive Board, or IMF management.

$$
\text { I N TER N A T | O N A L M O N E T A R Y F U N D }
$$




\title{
IMF Working Paper
}

Institute for Capacity Development

\section{Monetary Policy Is Not Always Systematic and Data-Driven: Evidence from the Yield Curve ${ }^{1}$}

Prepared by Aleš Bulíř and Jan Vlček

Authorized for distribution by Norbert Funke

January 2020

\section{IMF Working Papers describe research in progress by the author(s) and are published to elicit comments and to encourage debate. The views expressed in IMF Working Papers are those of the author(s) and do not necessarily represent the views of the IMF, its Executive Board, or IMF management.}

\begin{abstract}
Does monetary policy react systematically to macroeconomic innovations? In a sample of 16 countries - operating under various monetary regimes - we find that monetary policy decisions, as expressed in yield curve movements, do react to macroeconomic innovations and these reactions reflect the monetary policy regime. While we find evidence of the primacy of the price stability objective in the inflation targeting countries, links to inflation and the output gap are generally weaker and less systematic in money-targeting and multiple-objective countries.
\end{abstract}

JEL Classification Numbers: E43, E52, E58, G12

Keywords: Monetary transmission, yield curve, rule-based monetary policy

Author’s E-Mail Address: abulir@imf.org; janvlcekatcz@gmail.com

\footnotetext{
${ }^{1}$ We are indebted to Andy Berg, Yu-Chin Chen, Michal Franta, Gunes Kamber, Laura Kodres, Adam Kučera, Norbert Funke, Adam Remo, Marika Santoro, and Tao Wu for valuable suggestions and improvements. The paper benefited from comments in IMF and Czech National Bank seminars. The views expressed are those of the authors and do not necessarily reflect the official view of the IMF or CNB.
} 
Contents

Page

1. Introduction

2. Methodology and Hypotheses

3. Data Issues

3.1 Sample Countries

3.2 Macroeconomic Developments

3.3 The Yield Curve

4. Results

4.1 Country-Specific Results

4.2 Robustness Checks

5. Policy Implications

6. Conclusions

References

Tables

1. Sample Stylized Facts

2. Summary Results - Impulse Response Evidence

3. Summary Results - Impulse Response Evidence

4. Summary Results - Sample Correlation Evidence

5. Robustness Checks: Impulse Response Evidence Based on the Risk-Free Rate

6. Robustness Checks: Impulse Response Evidence Adjusted for the Financial Cycle

Figures

1. Policy Innovations Under Alternative Inflation Expectations

2. - 5. Macroeconomic Developments and the First Two Latent Factors

6. - 9. Do Policies React to Macroeconomic Developments?

10. Debt-to-GDP Ratio (In percent of GDP)

Appendices

A. Vector Autoregression Evidence

B. Macroeconomic Developments and Latent Factors

C. Impulse Response Results for Individual Countries

D. Correlation Results for Individual Countries

E. How Robust Are Our Results to Alternative Trend Assumptions and to the

$\underline{30}$

Removal of the Risk Premium?

F. Is There Fiscal Dominance in the Sample Countries? 


\section{Introduction}

We ask whether central banks adjust their policy rates in response to macroeconomic developments and what these adjustments signal about inflation expectations. Following Taylor (1993) and Henderson and McKibbin (1993), economists think of the conduct of monetary policy as a systematic, rulebased response to information about key macroeconomic conditions, rather than as a period-by-period optimization problem. As summarized in the New Keynesian paradigm by Galí (2018), central banks are expected to adjust the policy rate sufficiently strongly in response to variations in inflation and output, with the primacy of inflation stabilization thought to be the first-best policy. ${ }^{1}$ Monetary tightening can result either in a vertical shift of the yield curve or in a movement in the short-term rate only, either flattening or steepening the yield curve. Most central banks have adopted, or are in the process of adopting, such frameworks. Empirically, Ang and others (2011) shown that the U.S. yield curve provides a powerful evidence of such a transmission mechanism. But do other central banks do what they say? And does the monetary regime play a role?

We explore the adherence to data- and rule-based monetary policy empirically by comparing key macroeconomic innovations with changes in the yield curve. First, we compute the annual rate of inflation, the output gap, and the real exchange rate gap, estimate the level shift and slope shift of the yield curve (the first two latent factors) using the Christensen, Diebold, and Rudebusch (2011) methodology, and calculate the corresponding passthrough from the macroeconomic variables to the latent factors. Second, we estimate country-specific vector autoregressions (VAR) with the latent factors and macroeconomic variables, and control for the global financial and business cycle. Our approach broadly follows Ang and others (2011).

The key added value of the paper is the empirical result confirming systematic adherence to the rule-based policy paradigm in a broad range of monetary policy regimes. We find that inflation and the output and real exchange rate gaps coincide with or precede, policy changes and are correlated with them. Or, to put it differently, we find that monetary policy in the sample institutions is generally predictable and data-driven. Furthermore, finding a link between macroeconomic developments and the slope factor could be an indication of anchored inflation expectations.

\footnotetext{
${ }^{1}$ In addition, some central banks have used the policy rate systematically to target a certain level or variance of the exchange rate (Frankel, 2019).
} 
The results are regime-dependent. The three advanced inflation-targeting central banks in our sample are found to react systematically to inflation and output innovations, with the reactions showing as both level and slope changes. Our findings are also broadly similar for evolving inflation-targeting countries, although the links to latent factors are somewhat less systematic and these countries pay attention to their exchange rate developments as well. Surprisingly, we find little evidence that inflation expectations are better anchored in advanced than in evolving inflation-targeting countries - the share of reactions through the level and slope factors is similar. The story is different for central banks that either target monetary aggregates or follow multiple objectives: interest rate setting appears to be only weakly related to the key macroeconomic variables.

In the remainder of the paper we proceed as follows. First, we outline our methodology. Second, we describe our sample. Third, we present our results and discuss robustness checks. Fourth, we sketch policy implications. The final section concludes. Data, detailed results, and robustness checks are presented in the Appendices.

\section{Methodology and Hypotheses}

Rule-based monetary policy employs readily observable macroeconomic variables in easy-to-understand policy reaction functions, (Al-Mashat and others 2018). Regarding the macroeconomic variables, the primacy of price stability is expressed in the form of an inflation target, output stabilization is measured as the deviation of real GDP from its steady state, that is, the output gap, and the external stability of the currency is measured by the real exchange rate gap or exchange rate appreciation/depreciation. ${ }^{2}$ Recently, the issue of linking monetary policy and financial stability purposes has been hotly contested. However, the general consensus is that while the monetary authority should keep an eye on financial stability, the main tool for maintaining financial stability should be the macroprudential policy framework (see Smets, 2014, and IMF, 2015a).

Assessing policymakers' reaction to the macroeconomic variables is challenging. On the one hand, most central banks have been communicating their

\footnotetext{
${ }^{2}$ Unlike inflation, the estimates of the output and real exchange rate gaps depend on the chosen estimation techniques and calibration assumptions, the length of the series, and so on. Nevertheless, output gap estimates are nowadays regularly published for virtually all countries, either by central banks, statistical offices, or private analysts.
} 
policy reaction functions through various channels. The foreword sections in the key policy documents of Sweden's Riksbank or the Czech National Bank are useful examples, but one can find similar descriptions for non-IT central banks in documents describing IMF-supported adjustment programs, on central bank websites, in policymakers' speeches, and so on. ${ }^{3}$ On the other hand, the intuitive focus on the policy rate and other official communications may lead to spurious results, as these can be disconnected from short-term interbank market, longer-term bond, and lending rates due to inefficient liquidity operations and the impact of inflation expectations. In addition, policy rates carry little information under a strict monetary-targeting regime, under which the effective policy rate is the interbank rate. Following Ang and Piazzesi (2003), rather than monitoring the policy rate in an ad hoc policy reaction function, we thus prefer to focus on the whole yield curve, distinguishing between its level and slope shifts.

The textbook view of the term structure of interest rates, Mishkin (1995), suggests that monetary policy innovations, as well as other domestic and external developments, result in level and slope shifts of the yield curve, with the relative pass-through to these two factors depending on whether inflation expectations are anchored or not. In countries where inflation expectations are anchored, monetary policy innovations are predominantly propagated through changes in the slope of the yield curve. Agents believe that the policy innovations are designed so as to return the rate of inflation to the target at the end of the monetary transmission period and, hence, policy tightening and loosening are seen as both credible and relatively short-lived events. Consequently, there is little need for an adjustment in long-run interest rates and most of the policy-related action happen along the short end of the yield curve through a flattening/steepening of its slope (the dashed line in Figure 1). ${ }^{4}$ Such a stylized view was found to hold for the U.S. for most of the sample period of 1952-2007 by Ang and others (2011).

In contrast, in countries where inflation expectations are linked to past inflation and/or where actual inflation is volatile, agents do not know either

\footnotetext{
${ }^{3}$ For example, see the Letter of Intent attached to the Republic of Tanzania Policy Support Instrument documents. Available at https://www.imf.org/ /media/Files/Publications/CR/2018/cr1811.ashx.

${ }^{4}$ Following the term structure theory of interest rates, the long-term interest rate with a maturity of $k$ months, $i_{t}^{k}$, is a function of all expected future policy rates. Hence, $i_{t}^{k}=i_{t}^{M P}+\sum_{i=1}^{k} \frac{E_{t} i_{t+i}^{M P}}{k}+$ tprem, where $i_{t}^{M P}$ is the policy rate with a monthly maturity and tprem is a time premium. Using the Fisher definition of the real interest rate, the equation can be rewritten as $i_{t}^{k}=i_{t}^{M P}+\sum_{i=1}^{k} \frac{\bar{r}+E_{t} \pi_{t+i}}{k}+t p r e m$, where $\pi$ stands for inflation and $\bar{r}$ for the natural rate of interest.
} 
Figure 1: Policy Innovations Under Alternative Inflation Expectations

Notes: The figure draws a hypothetical yield curve (the full line) and its reaction to policy tightening under anchored inflation expectations (the dashed line) reflected in a flatter yield curve, and under unanchored inflation expectations (the dotted line) reflected in a vertically-shifted yield curve.

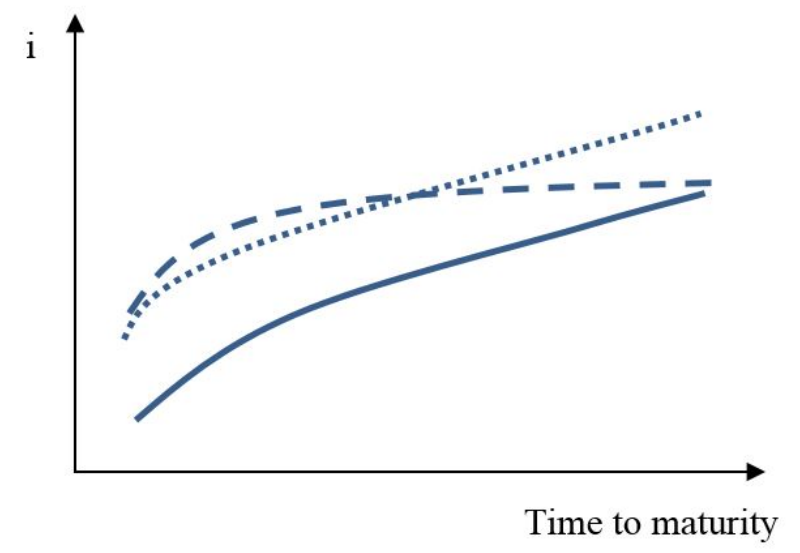

the true inflation objective or the policy horizon, or both. They tend to see policy innovations as possibly long-lasting events that necessitate a vertical shift of the yield curve (the dotted line in Figure 1), moving both short and long rates in tandem. Hence, a dominant link between inflation and the first factor - the level - is a good indicator of unanchored inflation expectations, and conversely a dominant link between inflation and the second factor indicates anchored expectations.

To obtain estimates of the latent factors, i.e. the level and slope shifts, we apply the Christensen, Diebold, and Rudebusch (2011), or CDR methodology, an arbitrage-free representation of the Nelson-Siegel yield curve model. See Bulír and Vlček (forthcoming) for a description.

The rule-based, data-driven policy paradigm defines the expected reactions of policy rates and various short- and long-term interest rates to current and future macroeconomic developments. ${ }^{5}$ A positive and unexpected inflation

\footnotetext{
${ }^{5}$ The authorities may not have the correct macroeconomic data at the time of the decision, of course. Orphanides (2001) demonstrated that U.S. Fed real-time policy recommendations differ considerably from those obtained with ex post revised data. The magnitude of the informational problems is likely to be larger in emerging and low-income countries. Needless to say, it is generally accepted that there have been important changes in the conduct of monetary policy before and after the Great Inflation episode, see Clarida,
} 
shock requires policy tightening through a hike in the short-term rate, resulting in either an upward level shift of the yield curve, or a flatter yield curve, or a combination of the two. ${ }^{6}$ Hence, one would expect to find a positive correlation between inflation and the first latent factor, and a negative correlation between inflation and the second latent factor, or both correlations.

Positive demand shocks as drivers of the output gap also imply higher interest rates to prevent future inflation. If the central bank additionally uses the interest rate to "systematically manage" the exchange rate, following depreciation one should again observe policy tightening. ${ }^{7}$ Furthermore, in countries with "managed floats" one would expect to find an "over-sized" importance of the link from the exchange rate to the yield curve, as the exchange rate developments effectively capture and accumulate all other shocks.

Why not look at expected macroeconomic developments - embedded in official macroeconomic forecasts - as opposed to past developments? After all, most central banks call their policies forward-looking, paying attention to expected developments as communicated in their macroeconomic forecasts. We see three reasons why our focus on contemporaneous and past innovations should suffice. First, to test whether the expected macroeconomic data lead today's interest rate developments, we would need officially published forecasts of the relevant macroeconomic variables - their realized observations in $t+i$ are biased to the extent they reflect the impact of current-period policy decisions. Such forecasts are unavailable for all but a few advanced-country central banks. Second, in our view, the various pass-through mechanisms are neither fast nor very forward-looking, as central banks tend to "smooth" their policy rate paths in line with the "wait and see" approach. Third, inflation and output - the two key elements of a typical policy reaction function exhibit strong serial correlation. Hence, we believe that a contemporaneous link between macroeconomic innovations and the latent factors is a fairly good approximation of a forward-looking monetary policy.

We test the transmission using VAR-based impulse responses and check the robustness of our findings with sample bivariate correlations. To this end,

Galí, and Gertler (2000).

${ }^{6}$ This policy reaction is certainly true for demand-driven inflationary developments. It could be argued that credible inflation targeters tend to ignore short-lived supply-driven inflation shocks and react only to the second-round effects thereof. For simplicity, we ignore the supply vs. demand distinction.

${ }^{7}$ By expressing the exchange rate in domestic currency terms, a positive first difference is equivalent to currency depreciation. The real exchange rate is calculated as the log of the nominal exchange rate plus the foreign price level minus the domestic price level. 
we check the sequencing between the observed developments in the macroeconomic variables and policy responses by observing the relevant impulse response in a VAR framework (see Appendix A for the VAR). We interpret the VAR equations as quasi policy reaction functions: how does the yield curve move in response to macroeconomic innovations, controlling for the global financial and business cycles?

\section{Data Issues}

Identification of the latent factors in emerging market countries (EMCs) and low-income countries (LICs) carries unique challenges. Government securities are rarely traded on secondary markets, primary issue data often contain gaps; some central banks provide liquidity at rates different from the policy rates, and so on. Ideally, we would have liked to estimate zero-coupon yield equivalents for bonds with coupons, but these are regularly available for advanced countries only, and estimation thereof for EMCs and LICs is hindered by a lack of benchmark issues. Furthermore, interest rate series in all countries have unit roots attributable to their disinflationary, or in some cases inflationary, periods that are difficult to remove - see Bulír and Vlček (forthcoming) for a discussion. The quality of national account data varies as well.

\subsection{Sample Countries}

We are primarily interested in testing the data-driven and rule-based policy paradigm in the widest possible range of monetary regimes, given data limitations, as opposed to re-examining data-rich U.S. or other advanced countries. Our macroeconomically and regime diverse sample contains 16 countries and the country selection is driven primarily by yield data availability, with the length of the country series ranging from seven years (Rwanda) to 24 years (Sweden), see Table 1. Such sample periods are much shorter than that used by Ang and others (2011), however, we see this as an advantage: we don't need to worry much about regime switches and time-varying loading coefficients.

Our diverse sample contains seven emerging market countries (EMCs) are Egypt (EGY), Georgia (GEO), Indonesia (IDN), Malaysia (MYS), Morocco (MAR), South Africa (ZAF), and Turkey (TUR). The six low-income countries (LICs) are Ghana (GHA), Kenya (KEN), Nigeria (NGA), Rwanda 
(RWA), Tanzania (TZA) and Uganda (UGA). The control group of three small open and advanced countries (ACs) comprises the Czech Republic (CZE), Israel (ISR), and Sweden (SWE). ${ }^{8}$ The ACs all practice inflationforecast targeting (Svensson, 1997), and five out of the 11 countries in the EMC/LIC group are identified as inflation targeters as well.

\subsection{Macroeconomic Developments}

The data for headline inflation, real GDP, and the exchange rate are either from the Haver databases or from national databases (see Appendix B, Figure 2, 3, 4, and 5; left-hand column). ${ }^{9}$ The CPI and exchange rate series are collected at monthly frequency and the rate of inflation and the rate of depreciation are calculated as the quarterly average of the year-on-year log-difference. Nonstationarity of the inflation series is removed by applying the Hodrick-Prescott filter with the usual smoothing coefficient for monthly data $(\lambda=14,400){ }^{10}$ The output and real exchange rate gaps are calculated by taking logs of quarterly real GDP and the CPI-based real exchange rate, applying the Hodrick-Prescott filter $(\lambda=1,600)$, and subtracting the trends, hence obtaining approximations of the gaps in percent of the trend values.

\subsection{The Yield Curve}

Only advanced and some emerging market central banks use the policy rate as an effective rate for liquidity operations - most LICs have occasionally provided liquidity at rates different from their official policy rates (see Berg and others 2013). Hence, we use the de jure policy rate only if the bank has used it consistently as a policy instrument and the interbank rates have

\footnotetext{
${ }^{8}$ We purposefully avoid re-examining the U.S., countries with large-scale unconventional monetary policy (Japan), or members of currency unions (Euro area).

${ }^{9}$ As a robustness check for the estimate of the real exchange rate gap we also estimate the risk premium in the uncovered interest parity (UIP).

${ }^{10}$ Filtering of the inflation series with the Hodrick-Prescott filter gives us, of course, a different inflation gap than those calculated as deviations from the typically constant official targets, in particular during inflationary or disinflationary periods. The key benefit of a time-varying inflation target is that we are more likely to capture an effective and/or credible inflation objective as opposed to a publicly announced but noncredible one. The credibility problem has been severe in some of sample inflation-targeting countries, such as Ghana or Indonesia. Ireland (2007) provided evidence in favor of a slowly evolving latent monetary policy objective, see also Castelnuovo, Greco, and Raggi (2008) for a literature review.
} 
Table 1: Sample Stylized Facts

\begin{tabular}{|c|c|c|c|c|c|}
\hline Country & MP regime & $\begin{array}{r}\text { Inflation, } \\
\text { in } \\
\text { percent }\end{array}$ & $\begin{array}{l}\text { Interbank } \\
\text { rate, in } \\
\text { percent }\end{array}$ & $\begin{array}{r}\text { Per capita } \\
\text { GDP, PPP } \\
\text { US\$ in } 2017\end{array}$ & Sample \\
\hline $\begin{array}{l}\text { Czech Republic } \\
\text { (CZE) }\end{array}$ & $\begin{array}{r}\text { Inflation targeting, } \\
\text { advanced }\end{array}$ & 2.1 & 1.8 & 36,915 & $2000 \mathrm{M} 4-2018 \mathrm{M} 3$ \\
\hline Israel (ISR) & $\begin{array}{r}\text { Inflation targeting, } \\
\text { advanced }\end{array}$ & 1.6 & 1.3 & 38,412 & 2008M1-2018M6 \\
\hline Sweden (SWE) & $\begin{array}{r}\text { Inflation targeting, } \\
\text { advanced }\end{array}$ & 1.2 & 2.6 & 50,069 & 1994M6-2018M6 \\
\hline Georgia (GEO) & Inflation targeting & 3.4 & 6.2 & 10,698 & 2010M9-2018M4 \\
\hline Ghana (GHA) & Inflation targeting & 12.7 & 18.0 & 4,641 & 2007M1-2018M4 \\
\hline Indonesia (IDN) & Inflation targeting & 6.2 & 7.6 & 12,283 & $2005 \mathrm{M} 7-2018 \mathrm{M} 6$ \\
\hline South Africa (ZAF) & Inflation targeting & 5.5 & 8.1 & 13,497 & 1999M12-2018M6 \\
\hline Turkey (TUR) & Inflation targeting & 8.5 & 11.3 & 27,916 & 2007M6-2018M6 \\
\hline Uganda (UGA) & $\begin{array}{r}\text { Monetary aggregate } \\
\text { targeting until } 2010, \\
\text { inflation targeting } \\
\text { thereafter }\end{array}$ & 6.7 & 11.0 & 1,863 & $2005 \mathrm{M} 1-2018 \mathrm{M} 6$ \\
\hline Egypt (EGY) & Multiple objectives & 6.6 & 9.2 & 11,582 & $2006 \mathrm{M} 7-2015 \mathrm{M} 4$ \\
\hline Malaysia (MYS) & Multiple objectives & 2.5 & 3.0 & 29,431 & $2008 \mathrm{M} 1-2018 \mathrm{M} 5$ \\
\hline Kenya (KEN) & $\begin{array}{r}\text { Monetary-aggregate } \\
\text { targeting }\end{array}$ & 8.9 & 7.4 & 3,285 & $2007 \mathrm{M} 1-2018 \mathrm{M} 5$ \\
\hline Morocco (MAR) & $\begin{array}{r}\text { Monetary-aggregate } \\
\text { targeting, exchange } \\
\text { rate peg }\end{array}$ & 1.5 & 3.0 & 8,217 & 2008M1-2018M6 \\
\hline Nigeria (NGA) & $\begin{array}{r}\text { Monetary aggregate } \\
\text { targeting }\end{array}$ & 10.6 & 12.0 & 5,860 & $2006 \mathrm{M} 9-2018 \mathrm{M} 6$ \\
\hline Rwanda (RWA) & $\begin{array}{r}\text { Monetary-aggregate } \\
\text { targeting }\end{array}$ & 4.0 & 6.5 & 2,035 & 2012M1-2018M6 \\
\hline Tanzania (TZA) & $\begin{array}{r}\text { Monetary-aggregate } \\
\text { targeting }\end{array}$ & 7.4 & 7.4 & 1,384 & 2003M1-2018M5 \\
\hline
\end{tabular}

Source: National databases; IFS database. 
been close to the central bank rate, otherwise we use the shortest maturity as the de facto policy rate. For maturities beyond 3 months, we occasionally have to rely on yields at issue on the primary market, as secondary markets are either nonexistent or illiquid. In turn, the primary market yields may be subject to non-market forces, as short maturities are used by the central bank for managing market liquidity, and demand for longer tenors is affected by regulatory measures targeting the capital and liquidity ratios of various financial institutions.

The empirical work is further complicated by secular movements in inflation and corresponding long-lasting movements in nominal interest rates. Such underlying trends tend to bias upward the importance of the level factor in our analysis. Individual yields cannot be detrended separately, as the underlying inflation trends need to be common across all maturities. To this end, we remove nonstationarity in all yields using the trend of the country's monetary policy rate (defined as the Hodrick-Prescott filter, $\lambda=14,400$ ). The filtering of the series implies that all yields are expressed as quasi term premiums and the cyclical component of the risk-neutral yield. Still, even after such detrending we cannot reject nonstationarity in about one fifth of all yields (see the online Appendix in Bulír and Vlček, forthcoming). The nonstationarity problem has been reported in earlier research; see, for example, Kim and Orphanides (2007) and Adrian, Crump, and Moench (2013).

We use the same calibration and estimation procedures for the CDR methodology to obtain the first two latent factors - the level and slope - in all sample countries. ${ }^{11}$ Visual observation of these factors in the right-hand column in Figures $2-5$ indicates that the level and slope develop differently in our sample countries. For example, in Malaysia and Sweden the slope movements seems to reinforce the level movements, while in the Czech Republic and most of the sub-Saharan countries no link seems immediately obvious. Furthermore, visually comparing the macroeconomic developments with the latent factors suggests the presence of correlation, albeit at varying leads and lags. We explore these links in the next section.

\section{Results}

The yield curves generally follow inflation and output gap developments, with the results for our advanced countries essentially mimicking the findings

\footnotetext{
${ }^{11}$ For the estimation details see the online Appendix in Buliřr and Vlček, forthcoming.
} 
by Ang and others (2011) (see Table 2). Intuitively, this finding can be understood as finding statistically significant coefficients for inflation and the output gap in an estimated policy reaction function.

The background results for the individual countries are summarized in Appendix C, Table 3 . In summary, in 11 out of 16 countries interest rates are linked to inflation, based on the impulse response evidence. A link between interest rates and output is found in 11 countries. The link between interest rates and the exchange rate gap has been found in ten countries. We discuss country-specific results in the next section and the full VAR results are presented in an online appendix. ${ }^{12}$ Appendix E presents selected robustness checks.

Table 2: Summary Results - Impulse Response Evidence

Notes: IT and IT_A indicate inflation targeting and advanced inflation targeting, respectively; Other comprises countries with monetary-aggregate-targeting and multiple-objective regimes. These sub-samples contain three, six, and seven countries, respectively.

The ratios indicate in what group of countries and for which relationship (i) we found the expected sign of the impulse response between the macroeconomic variables and the latent factors, and (ii) the impulse response estimate is statistically significant at a $p$-value of 0.2 at the horizon from $t$ to $t+2$. For example, the fourth and fifth columns of the IT_A row indicate that in all advanced ITers the yield curve reacts to the output gap, typically through both level and slope shifts.

\begin{tabular}{|l|c|c|c|c|c|c|}
\hline & \multicolumn{2}{|c|}{ Inflation } & \multicolumn{2}{c|}{ Output Gap } & \multicolumn{2}{c|}{ Exchange Rate } \\
\hline \hline & Level & Slope & Level & Slope & Level & Slope \\
\hline IT_A & $2 / 3$ & $2 / 3$ & $2 / 3$ & 1 & $1 / 3$ & 0 \\
\hline IT & $2 / 3$ & $2 / 3$ & $1 / 3$ & $1 / 3$ & 1 & 0 \\
\hline Other & $1 / 7$ & $3 / 7$ & $4 / 7$ & $2 / 7$ & $1 / 7$ & $2 / 7$ \\
\hline
\end{tabular}

Source: Authors' calculations; see Table 3 for individual-country results.

We prefer to express these quasi policy reaction functions in qualitative terms for two reasons. First, there is no obvious way of aggregating the level and slope shifts into a summary policy rate term. ${ }^{13}$ Second, given the wide estimated confidence bands, point estimates would give a false sense of precision.

\subsection{Country-Specific Results}

The primacy of the price stability objective implies that current-period (and recent past) inflation precedes the current-period latent factors. We expect

\footnotetext{
${ }^{12}$ See http://ales-bulir.wbs.cz/results_var_based_analysis_final.pdf

${ }^{13}$ Following Taylor (1993), the policy reaction function is typically expressed as policy rate $=$ neutral rate $+\alpha^{*}$ inflation gap $+\beta *$ output gap $+\ldots$
} 
statistically significant impulse responses; either sizable and negative for the second factor and nil for the first, or sizable and positive for the first factor and nil for the second, or both sizable with the correct signs (see Appendix $\mathrm{C}$ for details). We supplement the population-type evidence from the VARs with sample-type evidence from the Pearson correlation coefficients, see Appendix D, Figure 6, 7, 8, and 9 .

First, the advanced IT countries - the Czech Republic, Israel, and Sweden react to inflation and output developments either through the second latent factor or through both the first and second latent factors, and - given their freely floating exchange rates - all but the Czech Republic ignore exchange rate misalignments. The shapes of the impulse responses are flat after $t$ and $t+1$ and the estimated correlations are generally high, suggesting fast and robust reactions to macroeconomic innovations. The Czech yield curve appears to react one quarter faster to macroeconomic innovations than the Israeli or Swedish yield curves. In other words, Czech National Bank monetary policy seems to be more forward looking than that of the two other advanced countries. Furthermore, only in the Czech Republic, which has a strong exchange rate channel, do we find some evidence of a link between interest and exchange rates.

Second, the results for the other IT countries are more varied and generally weaker than those for the advanced ITers. These countries appear to react more often through the level factor to inflation and the output gap. In addition, we fail to find evidence of an inflation-to-interest rate link in Georgia and Ghana. All of them appear to react to the exchange rate, consistent with Frankel (2019).

Third, the results for multiple-objective and money-targeting central banks are even more varied. We fail to find evidence of the price stability objective in Malaysia, Nigeria, and Rwanda. Only in Kenya do we find links to both inflation and the business cycle.A link to exchange rates is found only in Kenya, Morocco, Nigeria, and Rwanda, all formally money-targeting countries.

\subsection{Robustness Checks}

These findings remain unchanged after a broad range of robustness checks, the results of which are available on demand. First, in addition to the Hodrick-Prescott filter, we apply the Hamilton (2017) filter and obtain results with similar signs. However, the level of statistical significance is gen- 
erally lower than that of the HP filter-based results. Second, we identify the risk-neutral rate in the CDR approach in order to eliminate the effect of the risk premium on the long end of the yield curve. Third, we also experiment with alternative calibrations of $\lambda$ in the Hodrick-Prescott filter to reflect the suggested higher smoothness to capture the financial cycle, again obtaining broadly similar results. For these two robustness checks see Appendix E, Table 5 and 6 . The only material differences are for three money-targeting countries in sub-Saharan Africa.

Fourth, although testing for structural breaks in our sample is difficult - our series are too short for formal Chow-like tests - we test shortening the sample to the post-2008 period and the results are again broadly similar. Fifth, the impulse response estimates are unaffected by choosing different criteria for the lag length in the VAR. Finally, we can rule out that the results are driven by fiscal dominance in the EMCs and LICs - see Appendix F. We leave to further research to extend the study to a sample of advanced countries that publish official macroeconomic forecasts - such a sample would allow the robustness checks by using consistent forecast variables rather than historical observations.

\section{$5 \quad$ Policy Implications}

Our findings answer two key questions: does monetary policy react to macroeconomic innovations, and through what channel(s) does monetary policy react to these innovations? First, monetary policy decisions, as expressed in yield curve movements, do react to macroeconomic innovations and these reactions reflect the monetary policy regime. On the one hand, we find clear evidence of the primacy of the price stability objective in the IT countries, especially the advanced ones. On the other hand, the links to inflation and the output gap are generally weaker and less systematic in both money-targeting and multiple-objective countries. Nevertheless, some money-targeting countries, such as Kenya, exercise monetary policy with an eye on both inflation and the business cycle. Others appear to loosely focus on one objective only, such as Malaysia on output. For Nigeria we fail to find any link in the baseline specification and some of the robustness checks. The fact that monetary policy in money targeting countries does not react to macroeconomic innovations in a forward-looking manner is hardly surprising - this finding results from both the nature and the execution of the monetary regime in 
most low-income countries (Berg and others, 2013). ${ }^{14}$

Second, we see a dividing line between the advanced and nonadvanced ITers with respect to exchange rate developments. While all nonadvanced ITers respond to exchange rate dynamics on top of inflation and the output gap, we found such a relationship in only one advanced ITer - the Czech Republic. This is a country with a strong exchange rate channel of monetary transmission and, furthermore, its central bank used an exchange rate commitment as an unconventional monetary policy instrument from November 2013 until April 2017 (see Franta and others 2018).

Third, we fail to reject the hypothesis that inflation expectations are equally well anchored in advanced and nonadvanced inflation-targeting countries. In our sample, the proportion of level and slope reactions to inflation and output gap developments is broadly similar in both groups. While surprising in itself, this result gives us some comfort that the real-time versus ex-post information problem is unlikely to be markedly different between the advanced and nonadvanced countries.

\section{Conclusions}

Examining a sample of 16 countries - operating under inflation-targeting, money-targeting, or multiple-objective regimes - we find that in most of them the yield curve responds to variations in inflation, output, and the exchange rate. In other words, monetary policy appears to be data- and rule-driven, irrespective of monetary regime and level of development and these results seem robust to various changes in the estimation techniques and yield curve transformations.

The evidence of the primacy of the price stability objective - policy responses to inflation - is strongest in the sample of advanced IT countries and, to a lesser degree, in the other IT countries. In contrast, links to inflation, output, and the exchange rate are generally weaker in multiple-objective countries, although in some money-targeting countries, we find evidence of inflation and output gap innovations influencing monetary policy decisions as reflected in yield curve movements. Almost all of the nonadvanced countries appear to keep an eye on the exchange rate.

\footnotetext{
${ }^{14}$ Under strict monetary targeting, the central bank does not react to new data and sticks to the preset path for the nominal monetary aggregate - see IMF (2015b).
} 


\section{APPENDICES}

\section{A Vector Autoregression Evidence}

We estimate a standard, open-economy VAR model for each country to assess the transmission of domestic macroeconomic innovations to the first two latent factors that describe interest rate behavior. The model has two lags $(p=2)$, three domestic macroeconomic variables (inflation expressed as the quarter-on-quarter log difference, $\pi$, the output gap identified from the HPfilter, $\hat{y}$, and the real exchange rate gap identified from the HP-filter of the CPI-based real exchange rate vis-à-vis the U.S. dollar, $\hat{z}$ ), and two measures of the yield curve derived from the CDR model, that is, level and slope estimates of the latent factors (DL1 and DL2, respectively). These five variables are treated as endogenous. In addition, the model is conditioned on two external and exogenous variables: the VIX index and world oil prices, both expressed as quarter-on-quarter log differences. These two series are proxies for the global financial cycle and global business cycle, respectively. All series, with the exception of interest rates, are from the Haver database. Impulse responses are defined as one-percent shocks using structural VARs, applying the following Choleski ordering restrictions: inflation, the output gap, the exchange rate gap, and the latent factors. 


\section{B Macroeconomic Developments and Latent Fac- tors}

In this section we present graphically the three macroeconomic variables of interest (inflation, the output and real exchange rate gaps) and the first two latent factors estimated using the CDR methodology. 
Figure 2: Macroeconomic Developments and the First Two Latent Factors

Notes: Inflation $(\pi)$ is calculated as the quarterly average from the detrended monthly year-onyear log-differences in the headline CPI, and the output gap (y gap) and the real exchange rate gap are estimated by applying the Hodrick-Prescott filter $(\lambda=1,600)$. The shift and slope latent factors are estimated using the CDR methodology and are denoted as DL1 and DL2, respectively.
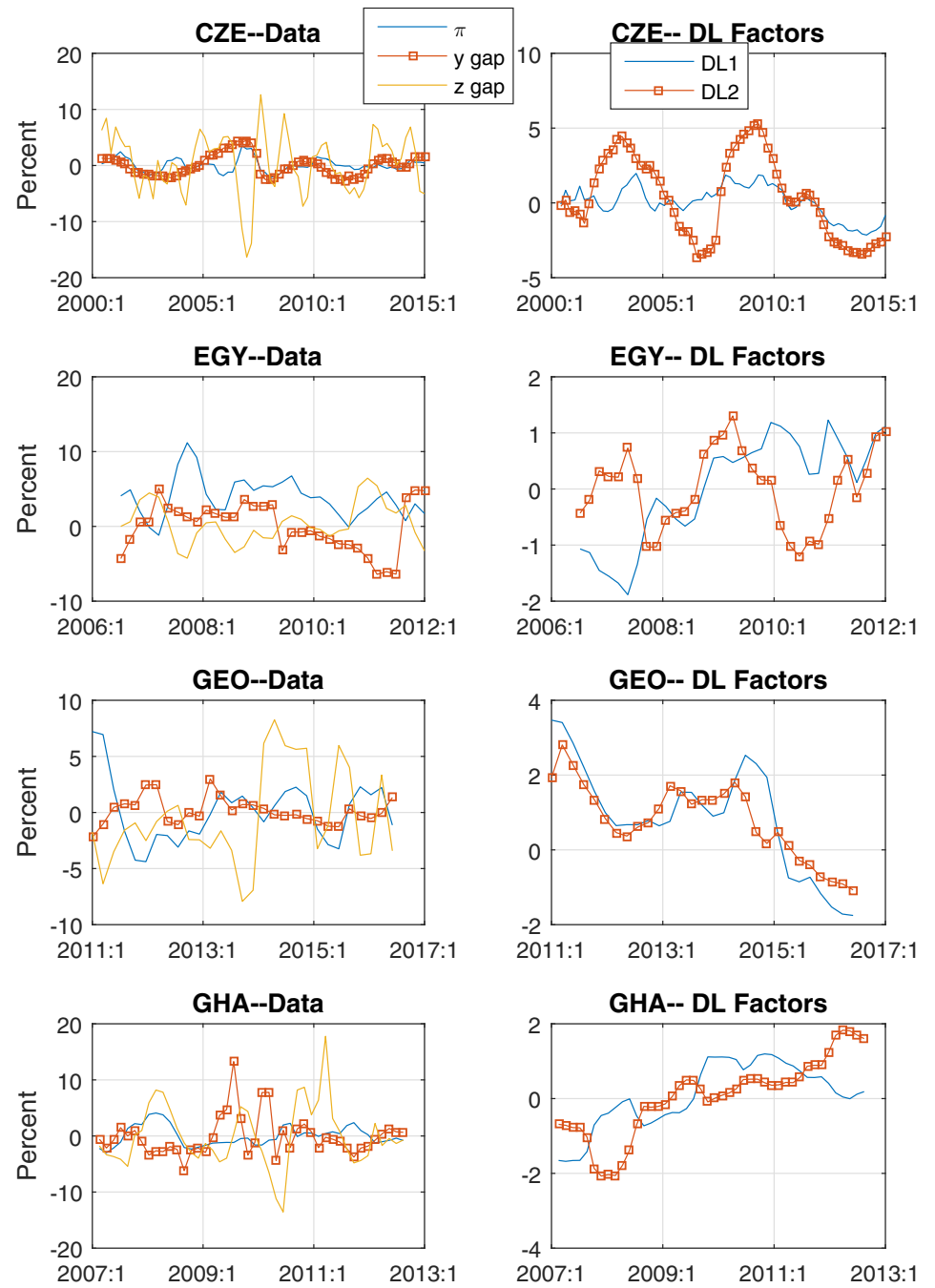

Source: Authors' calculations. 
Figure 3: Macroeconomic Developments and the First Two Latent Factors

Notes: Inflation $(\pi)$ is calculated as the quarterly average from the detrended monthly year-onyear log-differences in the headline CPI, and the output gap (y gap) and the real exchange rate gap are estimated by applying the Hodrick-Prescott filter $(\lambda=1,600)$. The shift and slope latent factors are estimated using the CDR methodology and are denoted as DL1 and DL2, respectively.
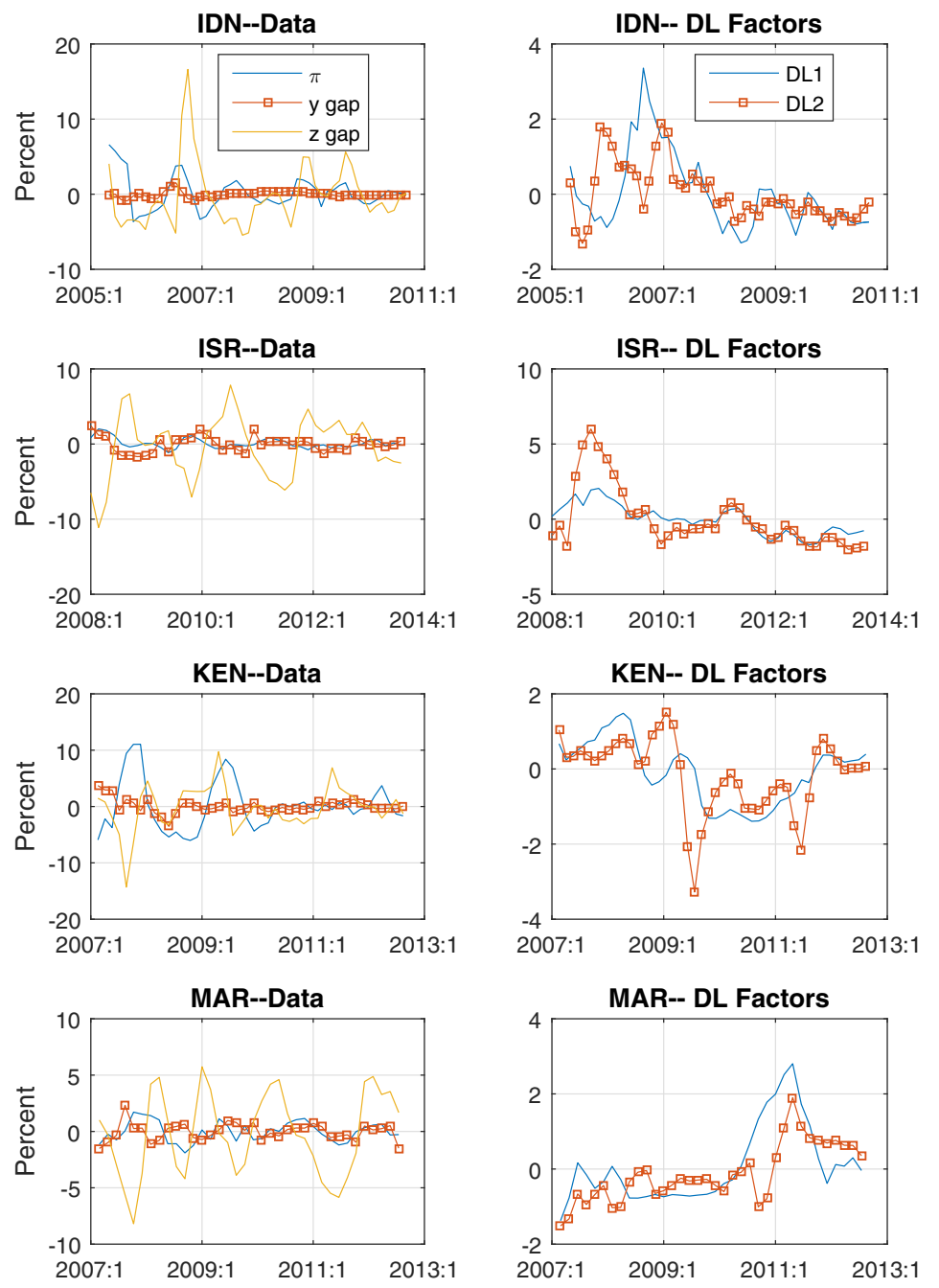

Source: Authors' calculations. 
Figure 4: Macroeconomic Developments and the First Two Latent Factors

Notes: Inflation $(\pi)$ is calculated as the quarterly average from the detrended monthly year-onyear log-differences in the headline CPI, and the output gap (y gap) and the real exchange rate gap are estimated by applying the Hodrick-Prescott filter $(\lambda=1,600)$. The shift and slope latent factors are estimated using the CDR methodology and are denoted as DL1 and DL2, respectively.
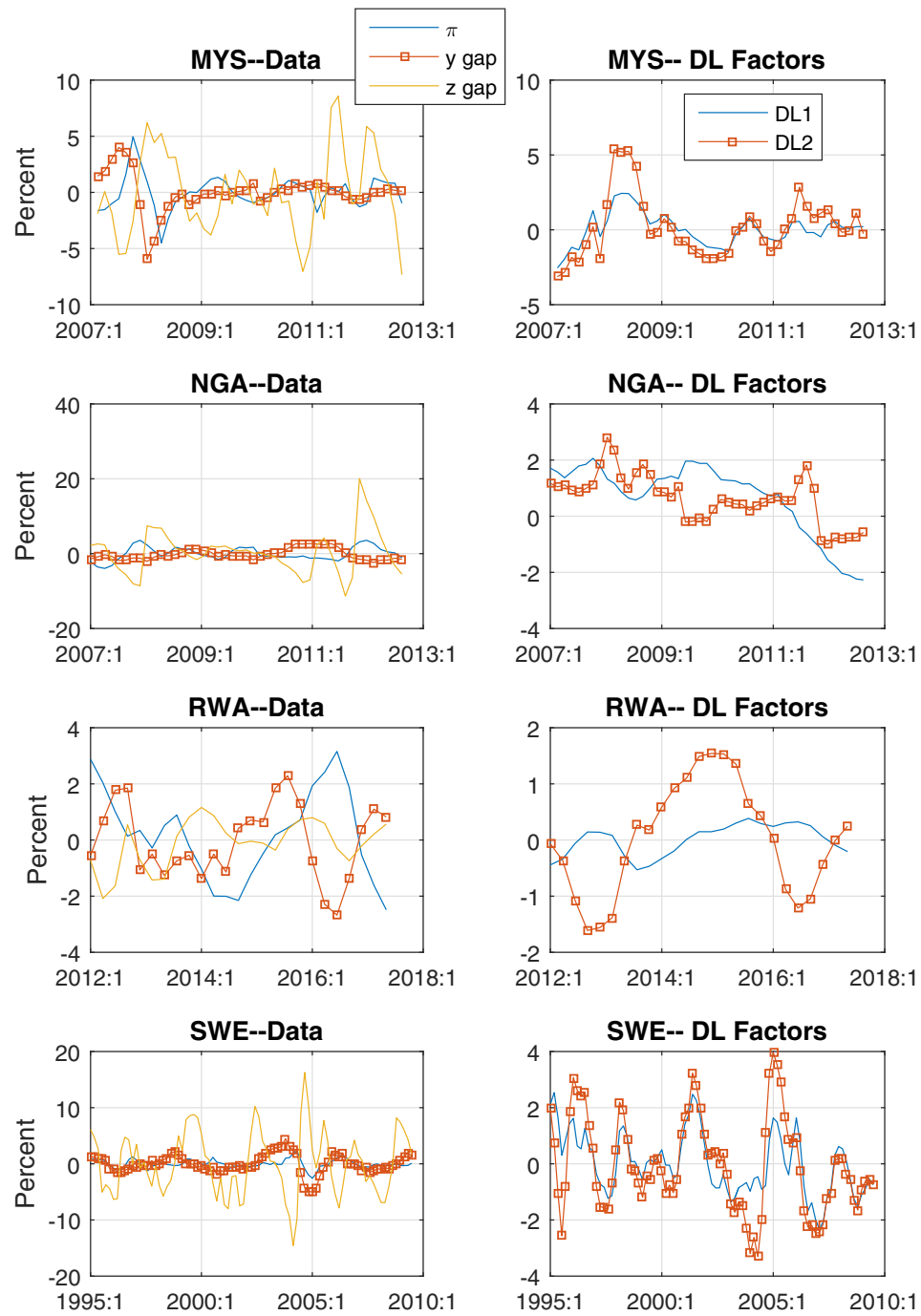

Source: Authors' calculations. 
Figure 5: Macroeconomic Developments and the First Two Latent Factors

Notes: Inflation $(\pi)$ is calculated as the quarterly average from the detrended monthly year-onyear log-differences in the headline CPI, and the output gap (y gap) and the real exchange rate gap are estimated by applying the Hodrick-Prescott filter $(\lambda=1,600)$. The shift and slope latent factors are estimated using the CDR methodology and are denoted as DL1 and DL2, respectively.
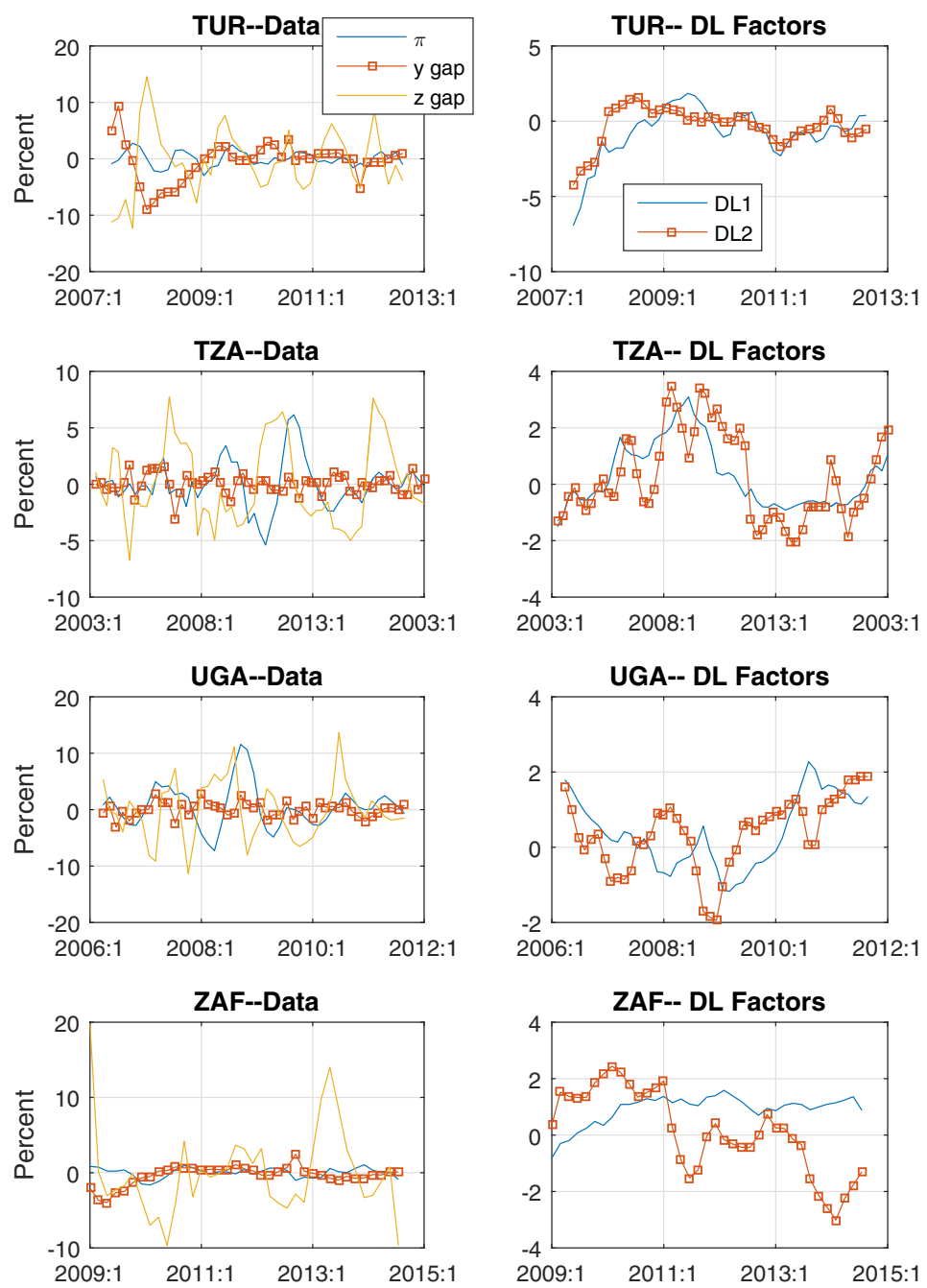

Source: Authors' calculations. 


\section{Impulse Response Results for Individual Coun- tries}

Table 3 summarizes our assessment of the individual-country VARs that form the basis for Table 2 in the main text. We denote by " $\mathrm{X}$ " each instance where we cannot reject at a $p$-value of 0.2 the null hypothesis of a link between the macroeconomic variables and the latent factors.

Table 3: Summary Results - Impulse Response Evidence

Notes: IT and IT_A indicate inflation targeting and advanced inflation targeting, respectively, MA indicates monetary-aggregate targeting, and MO indicates- multiple objectives. Uganda's monetary regime switched from money targeting to inflation targeting during our sample period.

$\mathrm{X}$ denotes instances where (i) we find the expected sign of the impulse response between the past macroeconomic variables and the latent factors and (ii) the estimate is statistically significant at a $p$-value of 0.2 at the horizon from $t$ to $t+2$;

- indicates that either no statistically significant impulse response is found or the response sign is going in the opposite direction to economic theory.

\begin{tabular}{|c|c|c|c|c|c|c|c|}
\hline \multirow[t]{2}{*}{ Country } & \multirow[t]{2}{*}{ Policy regime } & \multicolumn{2}{|c|}{ Inflation } & \multicolumn{2}{|c|}{ Output gap } & \multicolumn{2}{|c|}{ Exchange rate } \\
\hline & & Level & Slope & Level & Slope & Level & Slope \\
\hline Czech Republic & IT_A & $\mathrm{x}$ & $\mathrm{x}$ & - & $\mathrm{x}$ & $\mathrm{x}$ & - \\
\hline Israel & IT_A & $\mathrm{x}$ & - & $\mathrm{x}$ & $\mathrm{x}$ & - & - \\
\hline Sweden & IT_A & - & $\mathrm{x}$ & $\mathrm{x}$ & $\mathrm{x}$ & - & - \\
\hline Georgia & IT & - & - & - & - & $\mathrm{x}$ & - \\
\hline Ghana & IT & - & - & $\mathrm{x}$ & - & $\mathrm{x}$ & - \\
\hline Indonesia & IT & $\mathrm{x}$ & $\mathrm{x}$ & $\mathrm{x}$ & - & $\mathrm{x}$ & - \\
\hline South Africa & IT & $\mathrm{x}$ & $\mathrm{x}$ & - & - & $\mathrm{x}$ & - \\
\hline Turkey & IT & $\mathrm{x}$ & $\mathrm{x}$ & - & $\mathrm{x}$ & $\mathrm{x}$ & - \\
\hline Uganda & $\mathrm{MA} / \mathrm{IT}$ & $\mathrm{x}$ & $\mathrm{x}$ & - & $\mathrm{x}$ & $\mathrm{x}$ & - \\
\hline Egypt & MO & - & $\mathrm{x}$ & - & - & - & - \\
\hline Malaysia & MO & - & - & $\mathrm{x}$ & $\mathrm{x}$ & - & - \\
\hline Kenya & MA & - & $\mathrm{x}$ & $\mathrm{x}$ & - & - & $\mathrm{x}$ \\
\hline Morocco & MA & - & $\mathrm{x}$ & - & - & $\mathrm{x}$ & - \\
\hline Nigeria & MA & - & - & - & - & - & - \\
\hline Rwanda & MA & - & - & $\mathrm{x}$ & $\mathrm{x}$ & - & $\mathrm{x}$ \\
\hline Tanzania & MA & $\mathrm{X}$ & - & $\mathrm{x}$ & - & - & - \\
\hline
\end{tabular}

Source: Authors' calculations. 


\section{Correlation Results for Individual Countries}

We show both individual-country sample Pearson correlation coefficients and correlograms. Regarding the former, we denote by "X" instances where the correlation coefficient has the expected sign and its absolute value is larger than 0.3 (Table 4). ${ }^{15}$ Regarding the latter, we read the charts (Figure 6, 7, 8, and 9) as follows. The left-hand portion of each correlogram plots the correlations between the current-period and lagged macroeconomic variables (inflation and the output and exchange rate gaps) and the current-period first and second factors (DL1 and DL2, respectively). In other words, we test whether current and past macroeconomic data lead today's interest rate developments. The right-hand portion is for information only and should not be interpreted as a measure of forward-looking behavior of the yield curves, that is, future macroeconomic data leading today's interest rate developments.

\footnotetext{
${ }^{15}$ Although there are no critical points for correlation coefficients, Doucouliagos (2011) estimated that partial correlations bigger than \pm 0.3 can be deemed to be satisfactorily large.
} 
Table 4: Summary Results - Sample Correlation Evidence

Notes: IT and IT_A indicate inflation targeting and advanced inflation targeting, respectively, MA indicates monetary-aggregate targeting, and MO indicates multiple objectives. Uganda's monetary regime switched from money targeting to inflation targeting during our sample period.

$\mathrm{X}$ denotes instances where (i) we find the expected sign of the correlation coefficient between past macroeconomic variables and the latent factor, and (ii) the correlation coefficient is statistically significant;

- indicates either no statistically significant correlation found or the relationship is going in the opposite direction to economic theory.

\begin{tabular}{|c|c|c|c|c|c|c|c|}
\hline \multirow[t]{2}{*}{ Country } & \multirow[t]{2}{*}{ Policy regime } & \multicolumn{2}{|c|}{ Inflation } & \multicolumn{2}{|c|}{ Output gap } & \multicolumn{2}{|c|}{ Exchange rate } \\
\hline & & Level & Slope & Level & Slope & Level & Slope \\
\hline Czech Republic & $\mathrm{IT} \_\mathrm{A}$ & - & $\mathrm{x}$ & - & $\mathrm{x}$ & - & - \\
\hline Israel & IT_A & $\mathrm{X}$ & - & - & $\mathrm{X}$ & - & $\mathrm{X}$ \\
\hline Sweden & $\mathrm{IT}_{-} \mathrm{A}$ & - & - & - & $\mathrm{x}$ & - & - \\
\hline Georgia & IT & $\mathrm{X}$ & $\mathrm{X}$ & - & $\mathrm{x}$ & - & - \\
\hline Ghana & IT & - & $\mathrm{X}$ & $\mathrm{x}$ & - & - & $-\mathrm{X}$ \\
\hline Indonesia & IT & $\mathrm{x}$ & $\mathrm{x}$ & $\mathrm{X}$ & - & $\mathrm{x}$ & - \\
\hline South Africa & IT & - & $\mathrm{x}$ & $\mathrm{x}$ & - & - & - \\
\hline Turkey & IT & - & $\mathrm{X}$ & $\mathrm{X}$ & - & $\mathrm{X}$ & - \\
\hline Uganda & $\mathrm{MA} / \mathrm{IT}$ & $\mathrm{X}$ & $\mathrm{X}$ & $\mathrm{x}$ & - & $\mathrm{x}$ & $\mathrm{X}$ \\
\hline Egypt & MO & $\mathrm{x}$ & $\mathrm{x}$ & - & $\mathrm{x}$ & - & - \\
\hline Malaysia & $\mathrm{MO}$ & - & - & $\mathrm{X}$ & $\mathrm{X}$ & - & - \\
\hline Kenya & MA & - & $\mathrm{X}$ & - & - & $\mathrm{X}$ & - \\
\hline Morocco & MA & - & - & - & - & - & $\mathrm{x}$ \\
\hline Nigeria & MA & $\mathrm{X}$ & - & - & $\mathrm{X}$ & $\mathrm{X}$ & - \\
\hline Rwanda & MA & - & $\mathrm{X}$ & $\mathrm{x}$ & - & $\mathrm{X}$ & - \\
\hline Tanzania & MA & - & - & - & - & - & - \\
\hline
\end{tabular}

Source: Authors' calculations. 
Figure 6: Do Policies React to Macroeconomic Developments?

Notes: Each correlogram plots the $t$-period estimate of the sample Pearson correlation coefficient between the latent factors, denoted as DL1 and DL2, and three lags and three leads for detrended inflation, the output gap (Y Gap), and the real exchange rate gap (Z Gap).

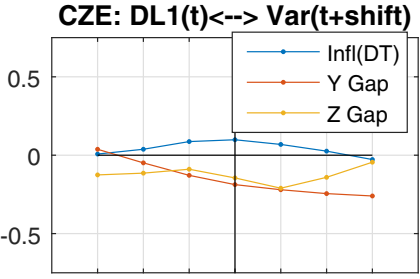

$\begin{array}{lllllll}t-3 & t-2 & t-1 & t & t+1 & t+2 & t+3\end{array}$

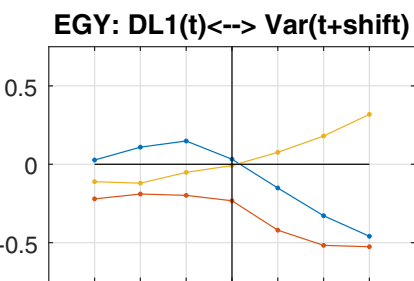

$\begin{array}{lllllll}t-3 & t-2 & t-1 & t & t+1 & t+2 & t+3\end{array}$

GEO: DL1(t)<--> Var(t+shift)

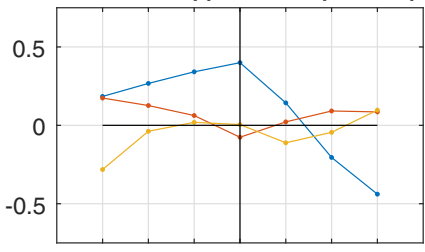

$\begin{array}{lllllll}t-3 & t-2 & t-1 & t & t+1 & t+2 & t+3\end{array}$

GHA: DL1(t)<--> Var(t+shift)

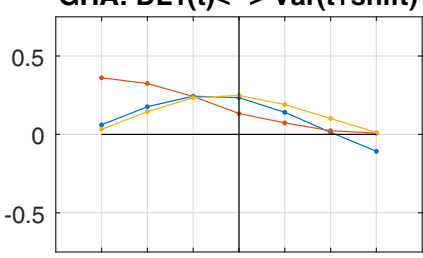

$t-3 \quad t-2 \quad t-1 \quad t \quad t+1 \quad t+2 t+3$
CZE: DL2(t)<--> Var(t+shift)

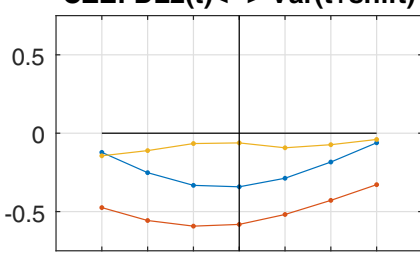

$t-3 \quad t-2 \quad t-1 \quad t \quad t+1 \quad t+2 \quad t+3$

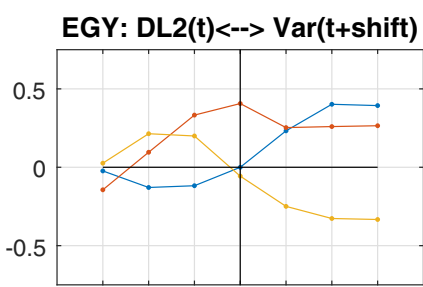

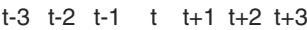

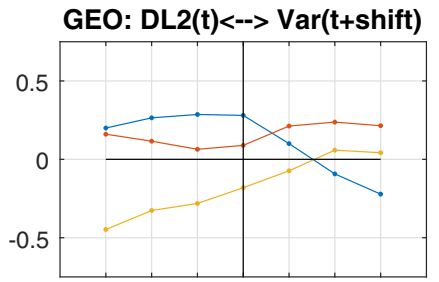

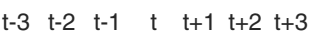

GHA: DL2(t)<--> Var(t+shift)

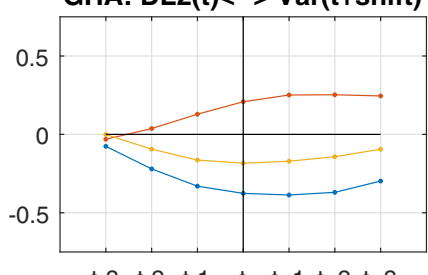

$t-3 \quad t-2 \quad t-1 \quad t \quad t+1 \quad t+2 \quad t+3$

Source: Authors' calculations. 
Figure 7: Do Policies React to Macroeconomic Developments?

Notes: Each correlogram plots the $t$-period estimate of the sample Pearson correlation coefficient between the latent factors, denoted as DL1 and DL2, and three lags and three leads for detrended inflation, the output gap (Y Gap), and the real exchange rate gap (Z Gap).

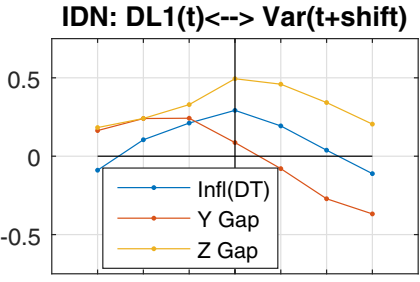

$\begin{array}{lllllll}t-3 & t-2 & t-1 & t & t+1 & t+2 & t+3\end{array}$

ISR: DL1(t)<--> Var(t+shift)

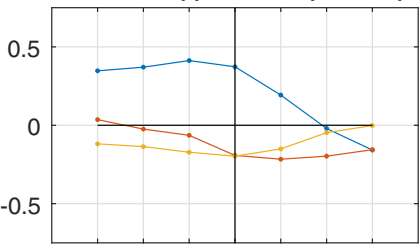

$t-3 \quad t-2 \quad t-1 \quad t \quad t+1 \quad t+2 t+3$

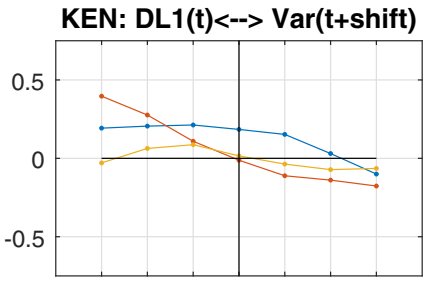

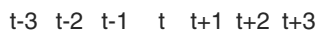

MAR: DL1(t)<--> Var(t+shift)

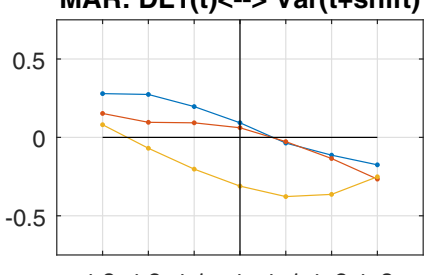

$\begin{array}{lllllll}t-3 & t-2 & t-1 & t & t+1 & t+2 & t+3\end{array}$

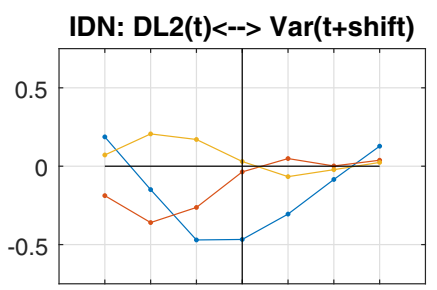

$t-3 \quad t-2 \quad t-1 \quad t \quad t+1 \quad t+2 t+3$

ISR: DL2(t)<--> Var(t+shift)

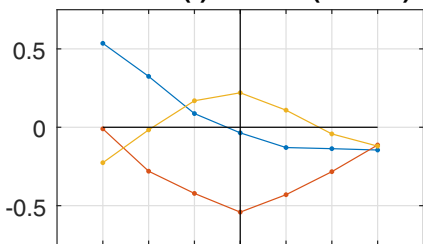

$t-3 \quad t-2 \quad t-1 \quad t \quad t+1 \quad t+2 \quad t+3$

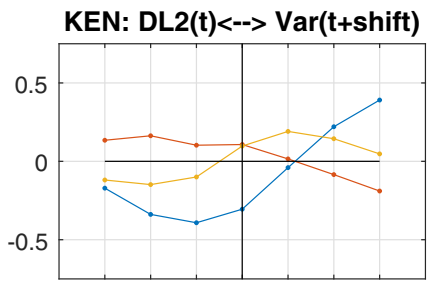

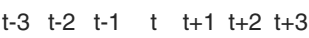

MAR: DL2(t)<--> Var(t+shift)

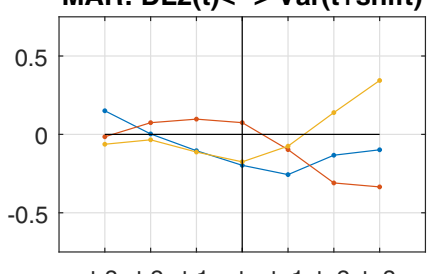

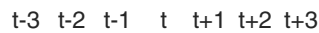

Source: Authors' calculations. 
Figure 8: Do Policies React to Macroeconomic Developments?

Notes: Each correlogram plots the $t$-period estimate of the sample Pearson correlation coefficient between the latent factors, denoted as DL1 and DL2, and three lags and three leads for detrended inflation, the output gap (Y Gap), and the real exchange rate gap (Z Gap).

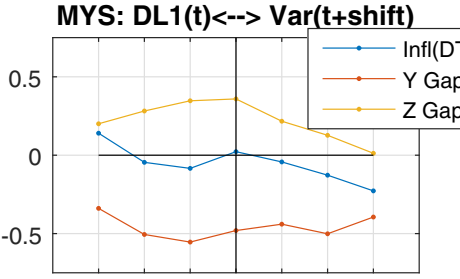

$\begin{array}{lllllll}t-3 & t-2 & t-1 & t & t+1 & t+2 & t+3\end{array}$

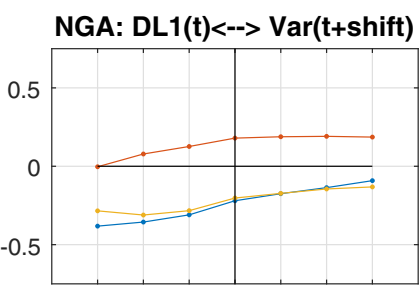

$\begin{array}{lllllll}t-3 & t-2 & t-1 & t & t+1 & t+2 & t+3\end{array}$

RWA: DL1(t)<--> Var(t+shift)

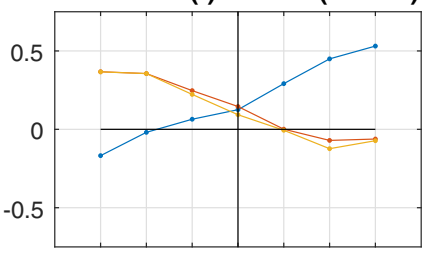

$t-3 \quad t-2 \quad t-1 \quad t \quad t+1 \quad t+2 t+3$

SWE: DL1(t)<--> Var(t+shift)

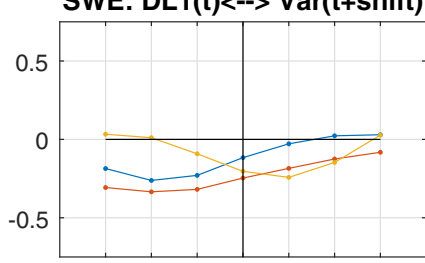

$\begin{array}{lllllll}t-3 & t-2 & t-1 & t & t+1 & t+2 & t+3\end{array}$
MYS: DL2(t)<--> Var(t+shift)

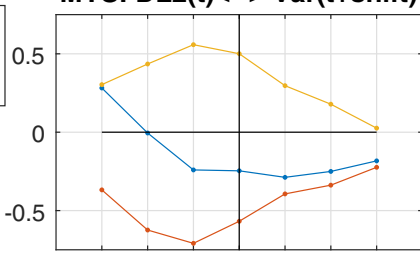

$t-3 \quad t-2 \quad t-1 \quad t \quad t+1 \quad t+2 t+3$

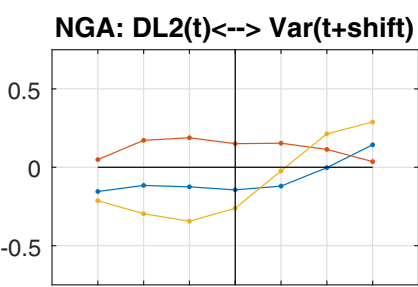

$t-3 \quad t-2 \quad t-1 \quad t \quad t+1 \quad t+2 t+3$

RWA: DL2(t)<--> Var(t+shift)

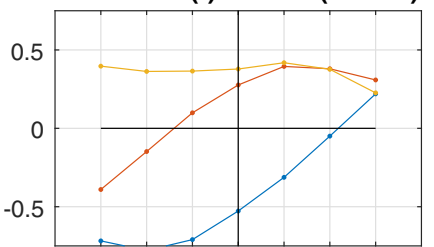

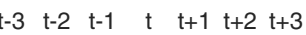

SWE: DL2(t)<--> Var(t+shift)

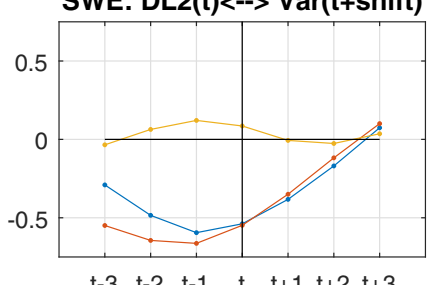

$t-3 \quad t-2 \quad t-1 \quad t \quad t+1 \quad t+2 \quad t+3$

Source: Authors' calculations. 
Figure 9: Do Policies React to Macroeconomic Developments?

Notes: Each correlogram plots the $t$-period estimate of the sample Pearson correlation coefficient between the latent factors, denoted as DL1 and DL2, and three lags and three leads for detrended inflation, the output gap (Y Gap), and the real exchange rate gap (Z Gap).

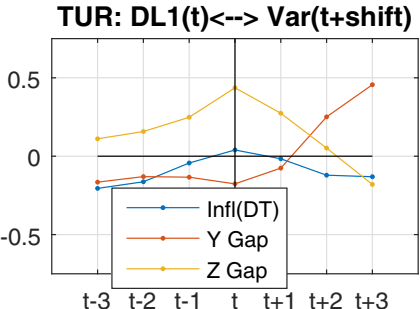

TZA: DL1(t)<--> Var(t+shift)

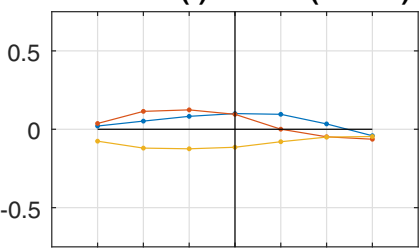

$\begin{array}{lllllll}t-3 & t-2 & t-1 & t & t+1 & t+2 & t+3\end{array}$

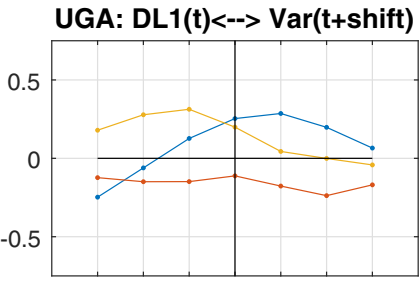

$t-3 \quad t-2 \quad t-1 \quad t \quad t+1 \quad t+2 t+3$

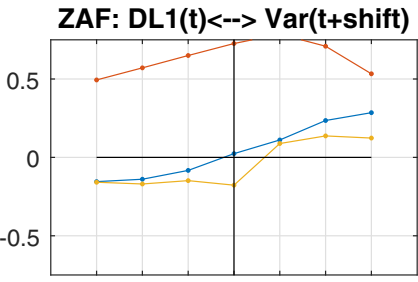

$\begin{array}{lllllll}t-3 & t-2 & t-1 & t & t+1 & t+2 & t+3\end{array}$

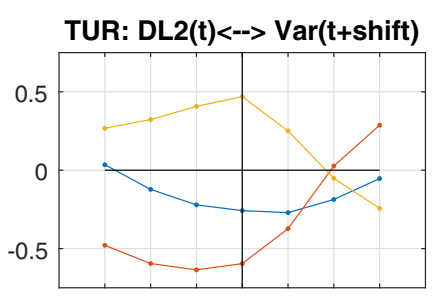

$\begin{array}{lllllll}t-3 & t-2 & t-1 & t & t+1 & t+2 & t+3\end{array}$

TZA: DL2(t)<--> Var(t+shift)

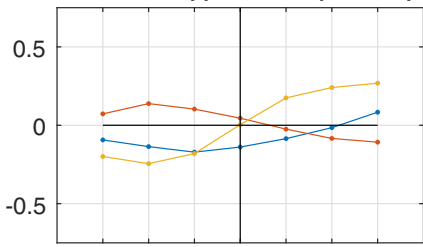

$t-3 \quad t-2 \quad t-1 \quad t \quad t+1 \quad t+2 t+3$

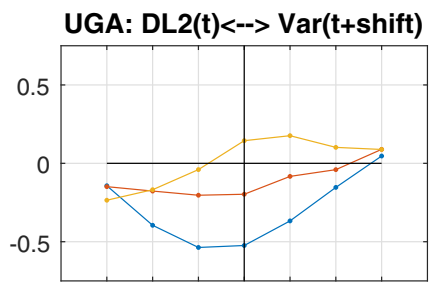

$t-3 \quad t-2 \quad t-1 \quad t \quad t+1 \quad t+2 t+3$

ZAF: DL2(t)<--> Var(t+shift)

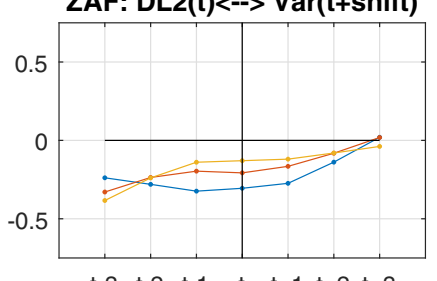

$t-3 \quad t-2 \quad t-1 \quad t \quad t+1 \quad t+2 \quad t+3$

Source: Authors' calculations. 


\section{E How Robust Are Our Results to Alternative Trend Assumptions and to the Removal of the Risk Pre- mium?}

Of the robustness checks mentioned previously, we report the results for the financial cycle and the removal of the risk premium. Interestingly, the only three countries where we observe materially different results - for both robustness checks - are Nigeria, Rwanda, and Tanzania: in Nigeria, the risk-free estimates and the smoother financial-cycle trend in the short rates newly identify some output and exchange rate gap links; however, we lose such links in the latter two countries.

Regarding the former robustness check, we tested the link between macroeconomic innovations and the yield curves using the estimate of the risk-free rate, that is, we removed the estimate of the risk premium as identified in the CDR methodology. While we find that the estimate of the risk-free rate results in different level/slope links for some countries, it does not change the thrust of our results.

Regarding the latter robustness check, it has been pointed out that financial cycles are longer in general than business cycles and, if this is the case, the optimal $\lambda$ might be higher. We replicate Table 3 in the main body of the paper with $\lambda$ set equal to 400,000 , a value recommended by the BIS for the identification of financial cycles. This alternative detrending technique again does not qualitatively change the results. 
Table 5: Robustness Checks: Impulse Response Evidence Based on the RiskFree Rate

Notes: Compared to the baseline estimate, we remove the CDR-based estimate of the risk premium from the yield curve.

\begin{tabular}{|c|c|c|c|c|c|c|c|}
\hline \multirow[t]{2}{*}{ Country } & \multirow[t]{2}{*}{ Policy regime } & \multicolumn{2}{|c|}{ Inflation } & \multicolumn{2}{|c|}{ Output gap } & \multicolumn{2}{|c|}{ Exchange rate } \\
\hline & & Level & Slope & Level & Slope & Level & Slope \\
\hline Czech Republic & $\mathrm{IT}_{-}{ }^{\mathrm{A}}$ & $\mathrm{X}$ & $\mathrm{x}$ & $\mathrm{X}$ & $\mathrm{x}$ & - & - \\
\hline Israel & $\mathrm{IT} \_\mathrm{A}$ & - & - & $\mathrm{X}$ & $\mathrm{X}$ & - & - \\
\hline Sweden & IT_A & $\mathrm{X}$ & $\mathrm{X}$ & $\mathrm{x}$ & $\mathrm{X}$ & - & - \\
\hline Georgia & IT & - & - & - & - & $\mathrm{x}$ & - \\
\hline Ghana & IT & $\mathrm{X}$ & $\mathrm{X}$ & $\mathrm{X}$ & - & $\mathrm{X}$ & - \\
\hline Indonesia & IT & $\mathrm{x}$ & $\mathrm{x}$ & - & - & $\mathrm{x}$ & - \\
\hline South Africa & IT & $\mathrm{X}$ & - & - & - & - & - \\
\hline Turkey & IT & $\mathrm{X}$ & $\mathrm{x}$ & $\mathrm{X}$ & $\mathrm{X}$ & $\mathrm{X}$ & - \\
\hline Uganda & $\mathrm{MA} / \mathrm{IT}$ & $\mathrm{X}$ & $\mathrm{X}$ & $\mathrm{X}$ & - & $\mathrm{X}$ & $\mathrm{X}$ \\
\hline Egypt & $\mathrm{MO}$ & $\mathrm{X}$ & $\mathrm{x}$ & - & - & - & - \\
\hline Malaysia & MO & - & - & $\mathrm{X}$ & $\mathrm{X}$ & - & - \\
\hline Kenya & MA & $\mathrm{X}$ & $\mathrm{X}$ & - & - & $\mathrm{X}$ & $\mathrm{X}$ \\
\hline Morocco & MA & $\mathrm{X}$ & $\mathrm{X}$ & - & - & $\mathrm{X}$ & $\mathrm{X}$ \\
\hline Nigeria & MA & - & - & $\mathrm{X}$ & - & $\mathrm{X}$ & $\mathrm{X}$ \\
\hline Rwanda & MA & - & - & $\mathrm{X}$ & - & - & - \\
\hline Tanzania & MA & - & - & - & - & - & - \\
\hline
\end{tabular}

Source: Authors' calculations. 
Table 6: Robustness Checks: Impulse Response Evidence Adjusted for the Financial Cycle

Notes: Compared to the baseline estimate, the trend of the short rate is derived from the HodrickPrescott filter with $\lambda$ equal to 400,000 .

\begin{tabular}{|c|c|c|c|c|c|c|c|}
\hline \multirow[t]{2}{*}{ Country } & \multirow[t]{2}{*}{ Policy regime } & \multicolumn{2}{|c|}{ Inflation } & \multicolumn{2}{|c|}{ Output gap } & \multicolumn{2}{|c|}{ Exchange rate } \\
\hline & & Level & Slope & Level & Slope & Level & Slope \\
\hline Czech Republic & $\mathrm{IT}_{-} \mathrm{A}$ & $\mathrm{x}$ & $\mathrm{x}$ & - & $\mathrm{x}$ & $\mathrm{x}$ & - \\
\hline Israel & $\mathrm{IT} \_\mathrm{A}$ & $\mathrm{x}$ & - & $\mathrm{x}$ & $\mathrm{x}$ & - & - \\
\hline Sweden & $\mathrm{IT}_{-} \mathrm{A}$ & - & - & - & - & - & - \\
\hline Georgia & IT & - & - & - & - & $\mathrm{x}$ & - \\
\hline Ghana & IT & $\mathrm{x}$ & - & - & - & $\mathrm{x}$ & - \\
\hline Indonesia & IT & $\mathrm{x}$ & $\mathrm{x}$ & - & - & $\mathrm{x}$ & - \\
\hline South Africa & IT & $\mathrm{x}$ & - & - & - & $\mathrm{x}$ & - \\
\hline Turkey & IT & $\mathrm{X}$ & - & - & $\mathrm{x}$ & $\mathrm{x}$ & - \\
\hline Uganda & $\mathrm{MA} / \mathrm{IT}$ & $\mathrm{X}$ & - & - & - & $\mathrm{x}$ & - \\
\hline Egypt & MO & - & - & - & - & - & - \\
\hline Malaysia & MO & - & - & $\mathrm{x}$ & $\mathrm{x}$ & - & - \\
\hline Kenya & MA & $\mathrm{x}$ & $\mathrm{x}$ & - & - & $\mathrm{x}$ & $\mathrm{x}$ \\
\hline Morocco & MA & - & $\mathrm{x}$ & - & - & $\mathrm{x}$ & - \\
\hline Nigeria & MA & - & - & - & - & - & - \\
\hline Rwanda & MA & - & - & $\mathrm{X}$ & $\mathrm{X}$ & - & $\mathrm{x}$ \\
\hline Tanzania & MA & $\mathrm{x}$ & - & - & - & - & - \\
\hline
\end{tabular}

Source: Authors' calculations. 


\section{F Is There Fiscal Dominance in the Sample Coun- tries?}

We fail to find empirical support for the hypothesis that the cross-country similarity of our results is driven by high public debt limiting movements in short- and long-term rates. In principle, difficult-to-finance public debt levels should impose high risk premiums, offsetting the policy rate innovations. At what level fiscal dominance will start playing such a role is, of course, subject to debate. To this end, we compare the sample-country debt-to-GDP ratios with the commonly used benchmark of 60 percent (Figure 10).

Most of our sample countries were below the 60-percent threshold during 2001-2016: the sample average was about 47 percent. About one-half of our sample countries had debt-to-GDP ratios in excess of 60 percent in 2001. However, by 2007 only Israel and Egypt remained, with the former gradually lowering its public debt to 62 percent in 2016. These two countries were joined by Morocco and Ghana in 2014, the latter mostly on account of rapid currency depreciation. Excluding these four countries, the 2015-2016 sample average was about 38 percent.

Figure 10: Debt-to-GDP Ratio (in percent of GDP)

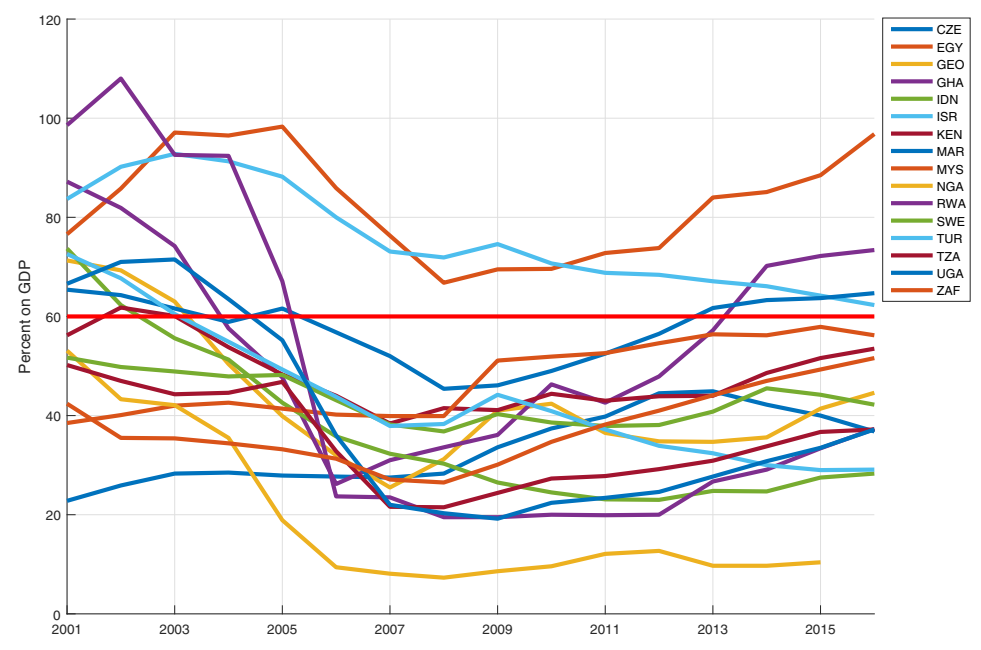

Source: Authors' calculations. 


\section{References}

[1] Adrian, Tobias, Richard K. Crump, and Emanuel Moench, 2013, "Pricing the Term Structure with Linear Regressions," Journal of Financial Economics, Vol. 110(1), pp. 110-138.

[2] Al-Mashat, Rania, Aleš Bulíř, N. Nergiz Dinçer, Tibor Hlédik, Tomáš Holub, Asya Kostanyan, Douglas Laxton, Armen Nurbekyan, Rafael Portillo, and Hou Wang, 2018, "An Index for Transparency for InflationTargeting Central Banks: Application to the Czech National Bank," IMFWP/18/210 (International Monetary Fund: Washington, DC).

[3] Ang, Andrew, Jean Boivin, Sen Dong, and Rudy Loo-Kung, 2011, "Monetary Policy Shifts and the Term Structure," The Rerview of Economic Studies, Vol. 78(2), pp. 429-457.

[4] Ang, Andrew, and Monika Piazzesi, 2003, "A No-Arbitrage Vector Autoregression of Term Structure Dynamics with Macroeconomic and Latent Variables," Journal of Monetary Economics, Vol. 50, pp.745-787.

[5] Berg, Andrew, Luisa Charry, Rafael A. Portillo, and Jan Vlček, 2013, "The Monetary Transmission Mechanism in the Tropics: A Narrative Approach," IMFWP/13/197 (International Monetary Fund: Washington, DC).

[6] Bulǐr, Aleš, and Jan Vlček, forthcoming, "Monetary Transmission: Are Emerging Market and Low-Income Countries Different?" Journal of Policy Modelling.

[7] Castelnuovo, Efrem, Luciano G. Greco, and Davide Raggi, 2008, "Estimating Regime-Switching Taylor Rules with Trend Inflation," Bank of Finland Research Discussion Paper No. 20/2008 (Bank of Finland: Helsinki).

[8] Christensen, Jens H.E., Francis X. Diebold, and Glenn D. Rudebusch, 2011, "An Affine Arbitrage-Free Generalized Nelson-Siegel Term Structure Model," Journal of Econometrics, Vol. 164(1), pp. 4-20.

[9] Clarida, Richard, Jordi Galí, and Mark Gertler, 2000, "Monetary Policy Rules and Macroeconomic Stability: Evidence and Some Theory," Quarterly Journal of Economics, Vol. 115, pp. 147-180. 
[10] Doucouliagos, Hristos, 2011, "How Large is Large? Preliminary and Relative Guidelines for Interpreting Partial Correlations in Economics," Deakin University Working Paper, SWP 2011/5.

[11] Frankel, Jeffrey, 2019, "Systematic Managed Floating," Open Economies Review, Vol. 30 (April), pp. 255-295.

[12] Franta, Michal, Tomáš Holub, and Branislav Saxa, 2018, "Balance Sheet Implications of the Czech National Bank's Exchange Rate Commitment ," Czech National Bank Working Paper, 10/2018. Available at: https://www.cnb.cz/export/sites/cnb/en/economicresearch/.galleries/research_publications/cnb_wp/cnbwp_2018_10.pdf.

[13] Henderson, Dale W, and Warwick McKibbin, 1993, "A Comparison of Some Basic Monetary Policy Regimes for Open Economies: Implications of Different Degrees of Instrument Adjustment and Wage Persistence." Carnegie-Rochester Conference Series on Public Policy, Vol. 39, pp. 221-318.

[14] Galí, Jordi, 2018, "The State of New Keynesian Economics: A Partial Assessment," NBER Working Paper No. 24845.

[15] Hamilton, James D, 2017, "Why You Should Never Use the HodrickPrescott Filter," Department of Economics, UC San Diego. Available at: http://econweb.ucsd.edu/ jhamilto/hp.pdf.

[16] IMF, 2015a, Monetary Policy and Financial Stability (International Monetary Fund: Washington, DC). Available at: http://www.imf.org/external/np/pp/eng/2015/082815a.pdf.

[17] IMF, 2015b, Evolving Monetary Policy Frameworks in Low-Income and Other Developing Countries (International Monetary Fund: Washington, DC). Available at: https://www.imf.org/external/np/pp/eng/2015/102315.pdf.

[18] Ireland, Peter, 2007, "Changes in Federal Reserve's Inflation Target: Causes and Consequences," Journal of Money, Credit and Banking, Vol. 39, pp. 1851-1882.

[19] Kim, Don H., and Athanasios Orphanides, 2007, "The Bond Market Term Premium: What Is It, and How Can We Measure It?" BIS Quarterly Review (June), pp. 27-40. 
[20] Mishkin, Frederic S., 1995, "Symposium on the Monetary Transmission Mechanism," Journal of Economic Perspectives, Vol. 9(4), pp. 3-10.

[21] Orphanides, Athanasios, 2001, "Monetary Policy Rules and Real-Time Data," American Economic Review, Vol. 91(4), pp. 964-985.

[22] Smets, Frank, 2014, "Financial Stability and Monetary Policy: How Closely Interlinked?" International Journal of Central Banking, Vol. 10, June, pp. 263-300. Available at: http://www.ijcb.org/journal/ijcb14q2a11.pdf.

[23] Svensson, Lars E.O., 1997, "Inflation Forecast Targeting: Implementing and Monitoring Inflation Targets," European Economic Review, Vol. 41 June, pp. 1111-1146.

[24] Taylor, John B., 1993, "Discretion Versus Policy Rules in Practice," Carnegie-Rochester Conference Series on Public Policy, Vol. 39, pp. 195-214. 